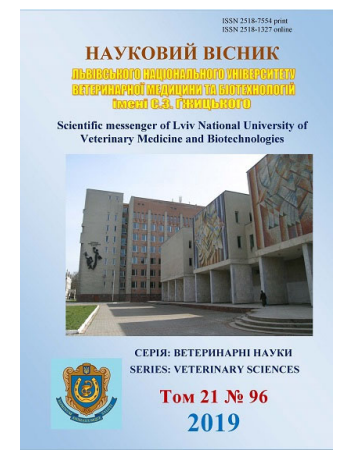

\author{
Науковий вісник Львівського національного університету \\ ветеринарної медицини та біотехнологій імені С.3. Гжицького. \\ Серія: Ветеринарні науки
}
Scientific Messenger of Lviv National University of Veterinary Medicine and Biotechnologies. Series: Veterinary sciences

\title{
Morphometric characteristics of embryonic development Heterakis dispar isolated from geese
}

\author{
V.V. Stybel, O.B. Prijma \\ Stepan Gzhytskyj Lviv National University of Veterinary Medicine and Biotechnologies, Lviv, Ukraine
}

Article info

Received 14.11.2019

Received in revised form 16.12.2019

Accepted 17.12.2019

Stepan Gzhytskyi National University of Veterinary Medicine and Biotechnologies Lviv, Pekarska Str., 50, Lviv, 79010, Ukraine. Tel.: +38-095-478-95-92 E-mail:vstybel@ukr.net
Stybel, V.V., \& Prijma, O.B. (2019). Morphometric characteristics of embryonic development Heterakis dispar isolated from geese. Scientific Messenger of Lviv National University of Veterinary Medicine and Biotechnologies. Series: Veterinary sciences, 21(96), $198-201$. doi: $10.32718 /$ nvlvet 9634

Knowledge of the biological properties and ecological environment of the development of helminths, especially those that cause invasive diseases of animals and humans, is extremely important for understanding the epizootic aspects and clinical manifestations of invasions. Among the domestic and wild birds, one of the dominant ones is the group of parasitic nematodes of the genus Heterakis Dujardin, 1845. The aim of this study was to study the peculiarities of the embryonic development of Heterakis dispar, isolated from domestic geese, taking into account their morphological and metrical changes. Experimental cultivation of eggs isolated from gonads of $H$. dispar females to their invasive stage in the laboratory. Morphological and metric changes in the process of their embryogenesis were established. The picking of nematodes was performed by the method of complete helminthological opening of the caecum of dead or forcedly killed geese. It has been determined that the eggs of nematodes of domestic geese of $H$. dispar species under the temperature regime of $22{ }^{\circ} \mathrm{C}$ undergo 4 stages of exogenous development: protoplast, crushing of blastomeres, formation of the larva of the first stage, formation of the larva of the second stage. At this temperature, the development of the parasites ended in 8 days, and the viability of the embryonic stages of the development of heteroxides was $79.33 \pm 0.88 \%$. In this case, developmental stoppage and death were observed in $20.67 \pm$ $0.88 \%$ of eggs. The protoplast stage occurred within 1-18 days, the formation of two blastomeres $-2-4$ days, the formation of the first stage larvae - 2-6 days, the formation of the second stage larvae - 4-8 days. In the process of exogenous development, the metric parameters of eggs of heterakises isolated from domestic geese change. Their sizes for cultivation from the stage of the protoplast to the larvae of the second stage are characterized by a significant decrease in width by 1.2 times and a simultaneous thinning of the shell by 1.1 times. Obtained data on the timing of the formation of invasive H. dispar eggs parasite in domestic geese, as well as their viability in the process of embryonic development can be used to improve the efficiency of species identification of isolated parasites by the results of scatoscopic studies of the bird.

Key words: geese, heterakosis, Heterakis dispar, nematode eggs, stages of development, morphological features, metric parameters.

\section{Морфометрична характеристика ембріонального розвитку Heterakis dispar, виділених від гусей}

\author{
В.В. Стибель, О.Б. Прийма
}

Львівський національний університет ветеринарної медицини та біотехнологій імені С.3. Гжсиького, м. Львів, Україна

Знання біологічних властивостей і екологічного середовища, де відбувається розвиток гельмінтів, особливо тих, щзо є збудниками інвазійних захворювань тварин і людини, надзвичайно важливо для розуміння епізоотичних аспектів і клінічного прояву інвазій. Серед домашньої та дикої птииі однією з домінуючих є група паразитичних нематод роду Неtеrakis Dujardin, 1845 . Метою 
роботи було вивчити особливості ембріонального розвитку Heterakis dispar, виділених від домашніх гусей, з урахуванням їх морфологічних і метричних змін. Проведено експериментальне культивування яєць, виділених з гонад самок Н. disраг, до їх інвазійної стадії в умовах лабораторії. Встановлювали морфологічні та метричні зміни у процесі їх ембріогенезу. Збір нематод проводили методом повного гельмінтологічного розтину сліпих кишок загиблих або вимушено забитих гусей. Визначено, цуо яйия нематод домашніх гусей виду H. dispar за температурного режиму $22{ }^{\circ}$ С проходять 4 стадії екзогенного розвитку: протопласта, дроблення бластомерів, утворення личинки периої стадї, утворення личинки другої стадії. За такої температури розвиток паразитів закінчувався за 8 діб, а життєздатність ембріональних стадій розвитку гетеракісів становила 79,33 \pm 0,88\%. При иьому зупинку в розвитку та загибель спостерігали у 20,67 \pm 0,88\% яєць. Стадія протопласта відбувалася впродовж 1-18 діб, утворення двох бластомерів - 2-4 діб, утворення личинки першої стадії-2-6 діб, утворення личинки другої стадї-4-8 діб. У процесі екзогенного розвитку змінюються метричні параметри яєць гетеракісів, виділених від домашніх гусей. Їх розміри за культивування зі стадії протопласта до личинки другої стадї характеризуються достовірним змениенням ширини у 1,2 раза та одночасним потониенням оболонки у 1,1 раза. Отримані дані щүодо термінів утворення інвазійних яєць Н. dispar, щчо паразитують у домашніх гусей, а також їх життєздатності у прочесі ембріонального розвитку можна використовувати для підвищення ефективності видової ідентифікацї виділених паразитів за результатами копроовоскопічних досліджень птиці.

Ключові слова: гуси, гетеракоз, Неterakis dispar, яйця нематод, стадї розвитку, морфологічні ознаки, метричні показники.

\section{Вступ}

Серед усіх живих організмів, що мешкають на Землі, нематоди займають лідируючі позиції серед інших представників фауни. Їх налічують не менше мільйона різновидів, і велика їх частина може паразитувати у людини, теплокровних і холоднокровних тварин, а також у рослин. Відомо, що паразитичні нематоди - невід'ємна частина біоценозів, де в екосистемах вони грають істотну роль, і крім використання значної частини енергї̈ екосистеми для своєї життєдіяльності вони можуть регулювати чисельність живих організмів - господарів (Castagnone-Sereno \& Danchin, 2014; Lok, 2016; Viney, 2017).

Серед домашніх і диких птахів однією з домінуючою відповідно до географічного і біотопічного розподілу є група паразитичних гельмінтів роду Heterakis Dujardin, 1845. Так, гетеракіси були виділені від домашніх курей, гусей, качок, куріпок, білолобих гусей, папугоподібних птахів, фазанів, дикорї водоплавної птиці у більшості країн світу, зокрема й в Україні. Причому екстенсивність ураження птиці збудником гетеракозу в окремих господарствах сягала 100\% (Bogach \& Taranenko, 2003; Cordón et al., 2009; Ogbaje et al., 2012; Hoque et al., 2014; Wongrak et al., 2014; Amundson et al., 2016; Boone et al., 2017).

Дослідниками відзначено, що типовим представником нематод роду Heterakis i найбільш поширеним видом у домашньої та дикої водоплавної птиці $\epsilon$ Heterakis dispar Schrank, 1790 (Gicik \& Arslan, 2003; Fedynich et al., 2005).

Показники чисельності гельмінтів, у тому числі H. dispar серед популяції водоплавної птиці залежать від особливостей біології паразитів і їх максимальної адаптації до найбільш широкого кола господарів. Вченими доведено, що даний паразит має прямий цикл розвитку. Водночас, вивченню особливостей розвитку яєць у $H$.dispar присвячені лише окремі наукові роботи (Madsen, 1950; Skrjabin et al., 1961).

Необхідно враховувати, що нематоди роду Heterakis, як й інші паразитичні організми, постійно знаходяться в стані біологічного прогресу, що супроводжується процесами морфологічних і біологічних змін. Це вимагає більш ретельного вивчення окремих стадій розвитку збудників гетеракозу, а також розро- бки нових підходів у підвищенні ефективності їх видової ідентифікації.

Метою роботи було вивчити особливості ембріонального розвитку Heterakis dispar, виділених від домашніх гусей, 3 урахуванням їх морфологічних i метричних змін.

\section{Матеріал і методи досліджень}

Дослідження проводилися упродовж 2019 року в лабораторії кафедри паразитології та іхтіопатології Львівського національного університету ветеринарної медицини та біотехнологій імені С.З. Гжицького.

3 метою вивчення біологічних особливостей ембріогенезу нематод $H$. dispar в лабораторних умовах виділяли яйця $з$ гонад самок гетеракісів. Збір нематод проводили методом повного гельмінтологічного розтину сліпих кишок загиблих або вимушено забитих гусей. Отриману культуру яєць поміщали в чашку Петрі і культивували в термостаті за температури $22{ }^{\circ} \mathrm{C}$ протягом 8 діб до появи в культурі інвазійних яєць 3 личинкою другій стадії. Кожен день культури переглядали під мікроскопом, звертали увагу на ступінь розвитку ембріону в яйцях, його морфологічні характеристики, також враховували кількість зруйнованих яєць. Експеримент проводили в трьох повторах.

3 метою вимірювання метричних характеристик ембріональних форм розвитку нематод $H$. dispar використовували програмне забезпечення ImageJ for Windows ${ }^{\circledR}$ (version 2.00) в інтерактивному режимі 3 використанням об'єктива $\times 5, \times 10, \times 40$ і окуляр $\times 10$.

Статистичну обробку результатів експериментальних досліджень проводили визначенням середнього арифметичного (M), його похибки (m) та рівня вірогідності (Р) 3 використанням таблиці t-критеріїв Стьюдента. Значення $\mathrm{P}<0,05$ вважали достовірним.

\section{Результати та їх обговорення}

Визначено, що яйця нематод домашніх гусей виду H. dispar за температурного режиму $22^{\circ} \mathrm{C}$ проходять 4 стадії екзогенного розвитку: протопласта, дроблення бластомерів, утворення личинки першої стадії, утворення личинки другої стадії. За такої температури розвиток паразитів закінчувався за 8 діб, а життєздат- 
ність ембріональних стадій розвитку гетеракісів становила 79,33 $\pm 0,88 \%$ (табл. 1 ).

Виділені культури яєць гетеракісів 100\%-во знаходилися на стадії протопласта. В подальшому, на 2 день культивування 25,67 $\pm 1,76 \%$ яєць залишалися ще на стадії протопласта, а більша їх кількість $(62,67 \pm 0,67 \%)$ знаходилися на стадії дроблення бластомерів. Лише $11,67 \pm 1,76 \%$ яєць вже містили всередині личинку першої стадії. На 4-ту добу культивування $39,00 \pm 1,53 \%$ яєць знаходилися на стадії утво- рення личинки першої стадії, 24,00 \pm 1,73\% - на стадії дроблення бластомерів. Водночас, невелика кількість яєць знаходилися на стадії протопласта $(2,33 \pm 0,88 \%)$ та стадії утворення личинок другої стадії (14,00 \pm 2,89\%). На 6-ту добу культивування найбільший відсоток яєць $(57,00 \pm 1,73 \%)$ містили личинку другої стадії (були інвазійними), а 22,33 $\pm 2,40 \%$ яєць містили ще личинок першої стадії. На 8-му добу $79,33 \pm 0,88 \%$ яєць дозрівали до інвазійної стадії, а $20,67 \pm 0,88 \%$ - зупинялися у розвитку та гинули.

Таблиця 1

Ембріональний розвиток яєць нематод Heterakis dispar, виділених від домашніх гусей $(\mathrm{n}=100)$

\begin{tabular}{lcccccc}
\hline \multicolumn{1}{c}{ Стадії розвитку } & \multicolumn{5}{c}{ Доби культивування } \\
\cline { 2 - 6 } & яєць & 1 -ша & 2-га & 4-та & 6-та & 8-ма \\
\hline Протопласта & 100,00 & $25,67 \pm 1,76$ & $2,33 \pm 0,88$ & - & - \\
Дроблення бластомерів & - & $62,67 \pm 0,67$ & $24,00 \pm 1,73$ & - & - \\
Утворення личинок першої стадії & - & $11,67 \pm 1,76$ & $39,00 \pm 1,53$ & $22,33 \pm 2,40$ & - \\
Утворення личинок другої стадії & - & - & $14,00 \pm 2,89$ & $57,00 \pm 1,73$ & $79,33 \pm 0,88$ \\
Загибель ясць & - & - & $20,67 \pm 0,88$ & $20,67 \pm 0,88$ & $20,67 \pm 0,88$ \\
\hline
\end{tabular}

Встановлено, що в процесі ембріонального розвитку H. dispar змінюються їх метричні параметри (рис. 1).

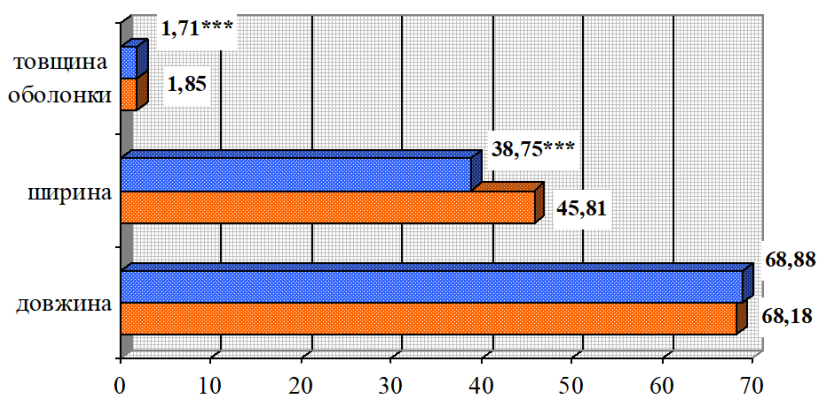

Рис. 1. Метричні параметри яєць Heterakis dispar у процесі їх ембріогенезу $(\mathrm{n}=15, \mathrm{M} \pm \mathrm{m}) ; * * * \mathrm{P}<0,001$

- відносно показників яєць на стадії протопласта

Так, метричні параметри яєць нематод виду H. dispar за культивування зі стадії протопласта до личинки другої стадії, характеризуються достовірним зменшенням ширини у 1,2 раза $(38,75 \pm 0,35$ мкм, $\mathrm{P}<0,001$ відносно 45,81 $\pm 0,47$ мкм) та одночасним потоншенням оболонки у 1,1 раза $(1,71 \pm 0,03$ мкм, $\mathrm{P}<0,001$ відносно $1,85 \pm 0,02$ мкм). Показники довжини яєць у процесі їх ембріогенезу не змінювалися і становили у яєць на стадії протопласта $68,18 \pm 0,39$ мкм, у інвазійних яєць $-68,88 \pm 0,48$ мкм.

В результаті вивчення в лабораторних умовах особливостей розвитку яєць гетеракісів виду H.dispar, що були виділені від домашніх гусей встановлено, що за їх морфологічними ознаками ембріогенез перебігав у чотири стадії: протопласта, дроблення бластомерів, утворення личинок першої та другої стадій. Причому, утворення інвазійних яєць $H$. dispar, виділених з гонад самок гельмінтів, відбувалося за 8 діб, де зі 100\% яєць на стадії протопласта формувалося 79,33 \pm 0,88\% інвазійних. Схожі дані були описані в науковій праці, де ембріогенез H. dispar закінчувався на 4 добу за температури $27^{\circ} \mathrm{C}$, а життєздатність становила 91,33 $1,53 \%$ (Yevstafyeva et al., 2018). Інші дослідники свідчать про формування інвазійних яєць $H$. dispar впродовж 5-6 діб за температури 20-24 ${ }^{\circ} \mathrm{C}$ (Hildenblat, 1956).

Також було встановлено, що метричні параметри яєць $H$. dispar зазнавали змін у процесі їх розвитку. Ширина яєць зменшувалася (у 1,2 раза, $\mathrm{P}<0,001$ ), а їх оболонка ставала тоншою (у 1,1 раза, $\mathrm{P}<0,001$ ). Такі зміни, на нашу думку, забезпечують даному виду гетеракісів високу життєздатність яєць в процесі їх розвитку. Отримані дані щодо термінів утворення інвазійних яєць $H$. dispar, що паразитують у домашніх гусей, а також їх життєздатності у процесі ембріонального розвитку можна використовувати для підвищення ефективності видової ідентифікації виділених паразитів за результатами копроовоскопічних досліджень птиці.

\section{Висновки}

Ембріональний розвиток нематод $H$. dispar, паразитуючих у домашніх гусей, проходить в чотири стадії: протопласта, дроблення бластомерів, утворення личинок першої та другої стадій, які мають характерні морфологічні відмінності. Встановлено, що за температури $22{ }^{\circ} \mathrm{C}$ в лабораторних умовах утворення інвазійних яєць $H$. dispar відбувається на 8 добу культивування, а їх життєздатність сягає 79,33 $\pm 0,88 \%$. Метричні параметри ембріональних стадій розвитку $H$. dispar характеризуються змінами в показниках ширини та товщини оболонки яєць.

Перспективи подальших досліджень полягають у визначенні впливу дезінфікуючих засобів на різні стадії розвитку яєць нематод виду H. dispar. 


\section{References}

Amundson, C.L., Traub, N.J., Smith-Herron, A.J., \& Flint, P.L. (2016). Helminth community structure in two species of arctic-breeding waterfowl Parasites and wildlife. International journal for parasitology, 5, 263272. doi: 10.1016/j.ijppaw.2016.09.002.

Bogach, M.V., \& Taranenko, I.L. (2003). Parazytarni hvoroby indykiv fermers'kyh i prysadybnyh gospodarstv Pivdnja Ukrai'ny [Parasitic diseases in turkeys in commercial and household farms of Southern Ukraine]. Ukrainian Black Sea Region Agrarian Science, 21, 311-317 (in Ukrainian).

Boone, E.C., Meiners, S.J., \& Laursen, J.R. (2017). Gut Helminth Composition in Newly Comigrating Light Geese (Lesser Snow Goose Chen caerulescens caerulescens and Ross' Goose Chen rossii). Comparative Parasitology, 84(1), 36-41. doi: 10.1654/1525-2647-84.1.36.

Castagnone-Sereno, P., \& Danchin, E.G. (2014). Parasitic success without sex - the nematode experience. Journal of Evolutionary Biology, 27(7), 1323-1333. doi: $10.1111 /$ jeb.12337.

Cordón, G.P., Prados, A.H., Romero, D., Moreno, M.S., Pontes, A., Osuna, A., \& Rosales, M.J. (2009). Intestinal and haematic parasitism in the birds of the Almuñecar (Granada, Spain) ornithological garden. Veterinary parasitology, 165(3-4), 361-366. doi: 10.1016/j.vetpar.2009.07.027.

Fedynich, A.M., Finger, R.S., Ballard, B.M., Garvon, J.M., \& Mayfield, M.J. (2005). Helminths of Ross' and Greater White-fronted Geese Wintering in South Texas, U.S.A. Comparative Parasitology, 72(1), 3338. doi: 10.1654/4159.

Gicik, Y., \& Arslan, M.O. (2003). The prevalence of helminths in the alimentary tract of geese (Anser anser domesticus) in Kars District, Turkey. Veterinary Research Communications, 27(5), 391-395. doi: 10.1023/A:1024710221179.

Hildenblat, A.A. (1956). Biologija vozbuditelej ganguleterakidoza gusej Heterakis dispar [Biology of Heterakis dispar, pathogen of ganguleterakidosis in geese]. Collection of Scientific Works of Moscow Veterinary Academy, 12, 207-213 (in Russian).
Hoque, M.A., Hassan, M.M., Haque, E., Shaikat, A.H., Khan, S.A., Alim, A., Skerratt, L.F., Islam, A., Tun, H.M., Dissanayake, R., Day, T.K., Debnath, N.C., \& Yamage, M. (2014). A survey of gastro-intestinal parasitic infection in domestic and wild birds in Chittagong and Greater Sylhet, Bangladesh. Preventive Veterinary Medicine, 117(1), 305-312. doi: 10.1016/j.prevetmed.2014.07.012.

Lok, J.B. (2016). Signaling in Parasitic Nematodes: Physicochemical Communication Between Host and Parasite and Endogenous Molecular Transduction Pathways Governing Worm Development and Survival. Current Clinical Microbiology, 3(4), 186197. doi: 10.1007/s40588-016-0046-2.

Madsen, H. (1950). Studies on species of Heterakis (nematodes) in birds. Danish Review of Game Biology, 1(3), 1-43.

Ogbaje, C.I., Agbo, E.O., \& Ajanusi, O.J. (2012). Prevalence of Ascaridia galli, Heterakis gallinarum and Tapeworm Infections in Birds Slaughtered in Makurdi Township. International Journal of Poultry Science, 11(2), 103-107. doi: 10.3923/ijps.2012.103.107.

Skrjabin, K.I., Shikhobalova N.P., \& Lagodovskaya E.A. (1961). Osnovy nematodologii: Oksiuratozy zhivotnyh i cheloveka [Essentials of nematodology. Oxyurata of animals and man]. Russian Academy of Sciences, Moscow (in Russian).

Viney, M. (2017). How Can We Understand the Genomic Basis of Nematode Parasitism? Trends in Parasitology, 33(6), 444-452. doi: 10.1016/j.pt.2017.01.014.

Wongrak, K., Daş, G., Moors, E., Sohnrey, B., \& Gauly, M. (2014). Establishment of gastro-intestinal helminth infections in free-range chickens: a longitudinal on farm study. Berliner und Münchener tierärztliche Wochenschrift, $\quad$ 127(7/8), 314-321. doi: 10.2376/0005-9366-127-314.

Yevstafyeva, V.A., Melnychuk, V.V., Nikiforova, O.V., Suprunenko, K.V., Korchan, L.N., Lokes-Krupka, T.P., Nehrebetskyi, I.S., \& Korchan, N.I. (2018). Comparative morphology and biology of nematodes of genus Heterakis (Nematoda, Heterakidae), parasites of the domestic goose (Anser anser) in Ukraine. Regulatory Mechanisms in Biosystems, 9(2), 229-236. doi: 10.15421/021834. 